Atıf: Ateş, E., Altundal Öncü, M., Bayar, R., Yılmaz, M. (2020). Eskişehir kentsel büyüme alanın Hücresel Otomat ve CAMarkov zincirleri ile analizi (1984-2056). Coğrafi Bilimler Dergisi/ Turkish Journal of Geographical Sciences, 18 (2), $276-$ 295, doi: $10.33688 /$ aucbd. 803432 .

Coğrafi Bilimler Dergisi

Turkish Journal of Geographical Sciences

e-ISSN:1308-9765

\title{
Eskişehir Kentsel Büyüme Alanın Hücresel Otomat ve CA-Markov Zincirleri ile Analizi (1984-2056)
}

\author{
Analysis of Eskişehir Urban Land Expansion With Cellular Automata and CA- \\ Markov chains (1984-2056)
}

Ersin Ateş̧, Merve Altundal Öncüa, Rüya Bayar*b, Mutlu Yılmaz

\begin{tabular}{l} 
Makale Bilgisi \\
\hline DOI: \\
10.33688/aucbd.803432 \\
\hline Makale Geçmişi: \\
Geliş: 28.09 .2020 \\
Kabul: 22.10.2020 \\
\hline Anahtar Kelimeler: \\
CA-Markov \\
Simülasyon Modelleri \\
Eskişehir \\
Kentsel Büyüme \\
CBS \\
\\
\hline Article Info \\
\hline DOI: \\
10.33688/aucbd.803432 \\
\hline Article History: \\
Received: 28.09 .2020 \\
Accepted: 22.10 .2020 \\
\hline Keywords: \\
CA-Markov \\
Simulation Models \\
Eskişehir \\
Urban Growth \\
GIS \\
\hline
\end{tabular}

\begin{abstract}
$\ddot{O} z$
Kentsel büyüme, sahip olduğu farkl dinamiklere bağll olarak zaman içerisinde mekânsal kullanım değişikliklerine yol açmaktadır. Bu değişiklerin yol açabileceği sorunlara karşı tedbirli olmak ve planlama yapabilmek için gelecekteki kent alanın yayılımını tahmin etmek oldukça önemlidir. Bu amaçla Eskişehir kentsel alanı 1984-2020 tarihleri baz alınarak incelenmis, uygulanan CA-Markov analizi ile 2056 yllındaki kentsel büyüme alanı ön görülmüştür. Çalışmanın sonuçlarına göre hızl kentleşme süreci yaşayan Eskişehir'de kentsel büyümenin gelecekte de devam edeceği tespit edilmiştir. Ayrıca büyümenin yönünün kuzeybatı-güneydoğu aksında devam etmesi beklenmektedir. Çalışmanın bulgularının Eskişehir için yapılan bir kentsel büyüme senaryosunda, başta kent plancıları olmak üzere, tüm karar alıcılara fayda sağlaması beklenmektedir.
\end{abstract}

\footnotetext{
* Sorumlu Yazar/Corresponding Author: rbayar@ankara.edu.tr

a Ankara Üniversitesi, Ayaş Meslek Yüksekokulu, Mimarlık ve Şehir Planlama Bölümü, Ankara/Türkiye, http://orcid.org/ 0000-0003-2402-9134

a Ankara Üniversitesi, Ayaş Meslek Yüksekokulu, Mimarlık ve Şehir Planlama Bölümü, Ankara/Türkiye, http://orcid.org/ 0000-0002-1956-2017

b Ankara Üniversitesi, Dil ve Tarih-Coğrafya Fakültesi, Coğrafya Bölümü, Ankara/Türkiye, http://orcid.org/ 0000-00033115-3707

b Ankara Üniversitesi, Dil ve Tarih-Coğrafya Fakültesi, Coğrafya Bölümü, Ankara/Türkiye, http://orcid.org/ 0000-00018914-1165
} 


\section{Giriş}

Sayıları her geçen gün hızla artan ve giderek daha geniş alanlara yayılmaya başlayan kentler, çoğu zaman arazi örtüsü üzerinde amaç dışı kullanımın yaygınlaşmasına ve ekonomik, ekolojik, sosyal pek çok problemin ortaya çıkmasına neden olmaktadır. Kentsel büyümenin pek çok boyutu olduğu ve zaman içerisinde mekânsal kullanım değişiklikleri yarattı̆̆ı düşünülürse; kentlerin farklı kentleşme dinamiklerine sahip olması, farklı hızda gelişmesi ve farklı arazi örtüsü özellikleri göstermesi, yayılım alanlarının ve sahip olduğu problemlerin de farklılaşmasına yol açmaktadır.

Kentleşme; sanayi ve ekonomik gelişmeye bağlı olarak kent sayısının artması ve bugünkü kentlerin büyümesi sonucunu doğuran, toplum yapısında artan oranda örgütleşme, iş bölümü ve uzmanlaşma yaratan, insan davranış ve ilişkilerinde kentlere özgü değişikliklere yol açan bir nüfus birikim süreci olarak tanımlanmaktadır (Keleş, 2010). Günümüzde yaşanan kentleşme süreci, kentleri hızla evirilen bir mekâna dönüştürmekle birlikte sürecin hızına bağlı olarak arazi örtüsü üzerindeki baskısını da arttırmaktadır. Bunun sonucu olarak kent ve çevresinde gecekondu alanları, kaçak yapılaşma, soylulaştırma, banliyöleşme, saçaklanma, kentsel dönüşüm projeleri ve arsa spekülasyonları vb. birtakım sorunlar meydana gelirken (Altundal Öncü, 2015), başta tarım ve doğal bitki örtüsü alanları olmak üzere yakın çevresindeki arazi örtüsü üzerinde de amaç dışı kullanıma bağlı problemlerin ortaya çıkmasına neden olmuştur. Tüm bu sorunlara yönelik tedbirlerin geliştirilerek çözüm yollarının bulunması ise kent alanlarının hangi yönde ne kadar büyüyeceğinin öngörülmesine bağlıdır. Bu nedenle kentsel alanının zamansal değişiminin tespit edilerek geleceğe yönelik tahminlerin yapılabilmesi planlama ve karar alma süreçlerinde önemli bir yere sahiptir.

Arazi örtüsü değişimleri, mekân süreçleri ve gelecek öngörüleri kapsamında son 10 yılda hazırlanan çalışmalarda Coğrafi Bilgi Sistemleri (CBS) ve Uzaktan Algılamaya dayalı simülasyon modelleri ön plana çıkmıştır (Alan vd., 2020; Aydın, 2011; Canpolat ve Dağlı, 2020; Cengiz ve Yılmaz, 2016; Halmy vd., 2015; Hamad vd., 2018; Iacona vd., 2012; Karip Bozkaya ve Göksel, 2017; Mammadov vd., 2019; Sang vd., 2011). Arazi örtüsü değişimini tespit eden bu modellerden en fazla kullanılanları CA-Markov, Markov Zinciri, CLUE, DINAMICA ve LCM'dir. Simülasyon modelleri ile arazi örtüsü çeşitliliğine etki eden doğal ve beşeri faktörler girdiler halinde sistem analizine dâhil edilmekte ve bunlar çıktı olarak mekânı tahmin ederek açıklamaktadır (Canpolat ve Dağlı, 2020). Söz konusu yöntemlerden en fazla öne çıkanı ve bu çalışmada kullanılanı ise CA-Markov modelidir. Bu model, sunduğu tahminlerin yüksek niteliğinden dolayı diğerlerinden ayrılmaktadır (Mas vd., 2014). CA-Markov modeli Markov zincirlerinden elde edilen tablo ve piksel verilerini analiz ederek geleceğe yönelik tahminde bulunmakta ve bu veriyi görsel bir çıktı olarak sunmaktadır. Temel girdi unsuru olarak farklı yıllara ait uydu görüntülerinin kullanıldığ 1 modelde, geçiş alanları ve geçiş olasılıkları matrisleri üretilerek değişimler ortaya konmaktadır. Böylece model, farklı tarihlerdeki arazi örtüsü sınıfları arasında ayrım yapabildiği gibi, sınıflar arasındaki geçiş oranını da tespit ederek gelecekteki durumlarını öngörebilmektedir (Behera vd., 2012; Çağlıyan ve Dağl1, 2015; Houet ve Hubert, 2006; Muller ve Middleton, 1994).

$\mathrm{Bu}$ çalışma Hücresel Otomat ve Markov Zincirleri modellerini entegre kullanarak, Eskişehir, kentsel alanının gelecekteki durumunu tahmin etmeyi amaçlamaktadır. Bu kapsamda Eskişehir kentsel 
alanının 1984-2020 tarihleri arasındaki büyümesi dikkate alınarak 2056 yılındaki Eskişehir kentsel alanı tahmin edilmiştir.

\section{2. Çalışma Alanının Yeri ve Sınırları}

Çalışma alanı olarak, sahip olduğu gelişmiş kentsel dinamikler nedeniyle hızlı kentleşme süreci yaşayan Eskişehir kenti seçilmiştir. İç Anadolu Bölgesi, Yukarı Sakarya Bölümü içerisinde yer alan Eskişehir ilinin kuzeybatısında bulunan Eskişehir kenti, önemli kara ve demiryolu kavşakları üzerinde bulunmaktadır. Kent aynı zamanda kuzeyde Sündiken Dağları ve Bozdağ, doğuda Sivrihisar ve güneyde Türkmen Dağları ile çevrili olan; Sakarya nehri kollarından Porsuk çayının ve ona dökülen Sarısu deresinin geçtiği, Eskişehir ovasının güneybatı kesiminde yer almaktadır (Şekil 1). Ayrıca, kentin arazi örtüsü üzerindeki yayılımının tespit edilebilmesi için kent yakın çevresinde bir çalışma alanı belirlenmiştir.

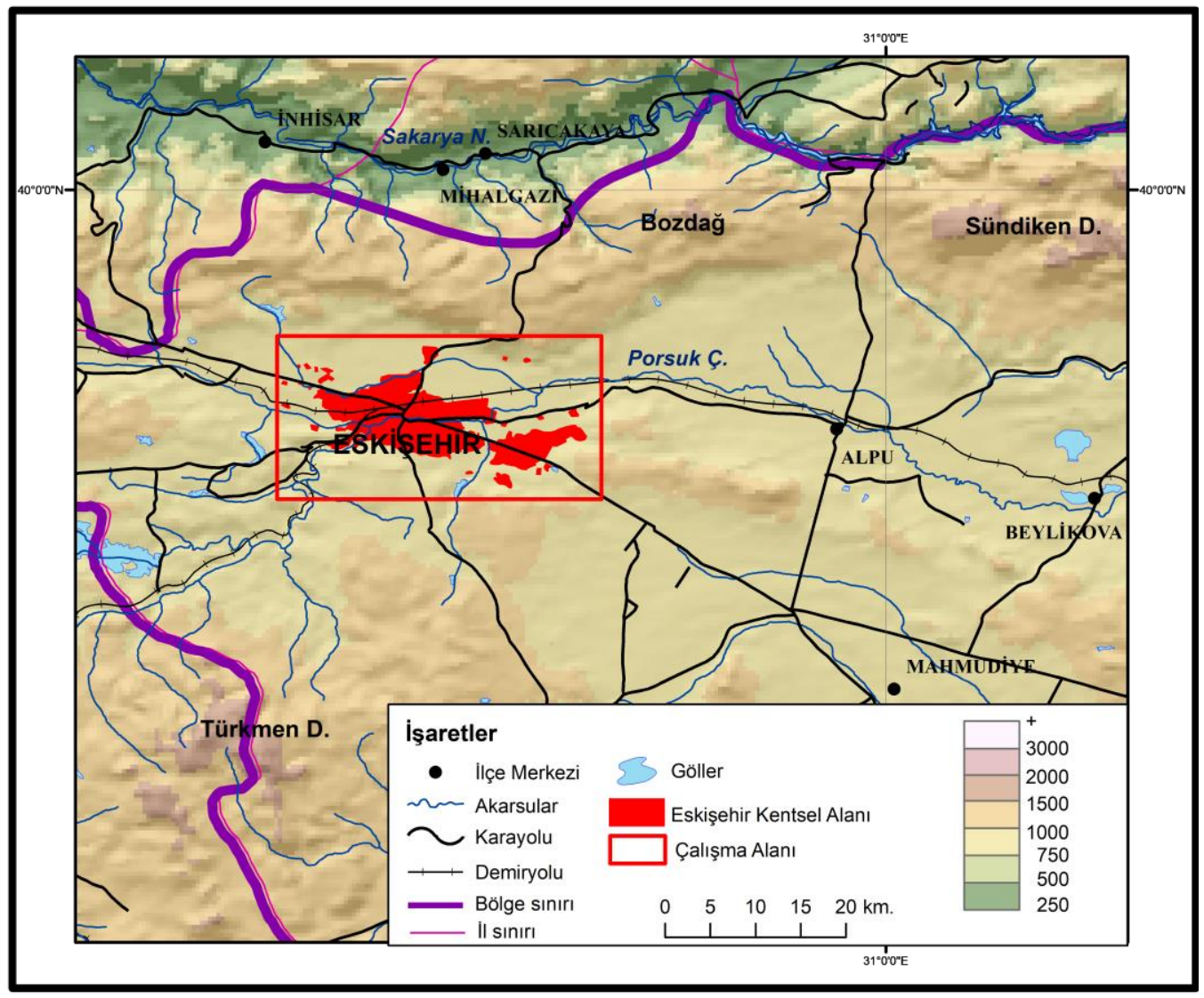

Şekil 1. Çalışma alanı (Eskişehir kentsel alanı ve yakın çevresi)

İlk çağlardan günümüze kadar yerleşim yeri olan (İlgar, 2008) Eskişehir, 1923 yılında il merkezi statüsü kazanmış, kamu yatırımlarının yapılmasıyla ticaret ve sanayi fonksiyonlarının önem kazandığı bir merkez olmuştur. Özellikle sanayileşmenin etkisiyle ortaya çıkan hızlı nüfus artışı yeni konut alanlarının inşa edilmesine neden olmuştur. Eskişehir'in alansal büyümesinde etkili olan bir diğer faktör ise göçler olmuştur. 1950-1951 yılları arasında başta Bulgaristan'dan olmak üzere Çerkez, Abaza ve Kırım Tatarları gibi pek çok farklı bölgeden göç almaya başlayan Eskişehir'de yeni alanları oluşmuş 
(Şahbaz, 2016) ve kent kuzeybatı-güneydoğu doğrultusunda gelişmeye devam etmiştir. Yurt dış1 göçlerinin yanı sıra yurt içinden de göç alan Eskişehir'de ulaşım aksları boyunca yeni konut alanları gelişmesini sürdürmüştür.

Nüfus artışı ve kentsel büyümeye bağlı olarak 1993 yılında büyükşehir belediyesi kurulan Eskişehir'de en belirgin fonksiyon sanayi olmuştur (Şahbaz, 2016). Ankara Karayolu üzerinde yer alan OSB, Türkiye'nin en büyük sanayi bölgelerinden biri durumundadır. Kent kimliğini belirleyen sanayi fonksiyonunun ardından ticaret, tarım ve eğitim fonksiyonları önem kazanmıştır. 1958 yılında kurulan Anadolu, 1993 yılında kurulan Eskişehir Osmangazi ve 2018 y1lında kurulan Eskişehir Teknik Üniversitelerinin kente dağılan yerleşkeleri sayesinde Eskişehir, bir üniversite kenti görünümü almaya başlamıştır ki, bu görünüm kentsel arazi kullanımının değişiminde ve kentin büyümesinde çok önemli bir paya sahip olmuştur. Kent nüfusunun 1980 y1lında 34.923 kişiden 2019 y1lında 783.611 kişiye yükselmesi aslında kentsel alan büyümesinin boyutu hakkında fikir vermektedir.

\section{Materyal ve Yöntem}

Günümüzde teknolojik gelişmelere bağlı olarak uzaktan algılama ve coğrafi bilgi sistemleri aracılığıyla kentsel büyüme alanlarının tespiti, analizi ve gelecek öngörüsü için pek çok model geliştirilmiştir. Bu modeller içerisinde en yaygın kullanıma sahip olanları CA-Markov Zincirleri'dir (Cellular Automata- Markov Chain).

Markov Zincirleri analizi gelecek dönemlerin tahmin edilebilmesi için mevcut olasılıkları kullanan bir yöntemdir (Timor, 2001). Modellemenin yapılabilmesi için mevcut durum ve geçiş olasılıklarının bilinmesi gerekir. Stokastik süreç, tekrarlanabilen bir gözlem dizisidir ve ortaya çıkan iki veya daha fazla sonuç bu süreçte olasılık kanunları ile belirlenir (Halaç, 2001). Markov zincirleri de, teknik matris cebiri ve olasıllk yasalarından yararlanarak karar vericilere bir sistemin mevcut özelliklerinde meydana gelebilecek davranış değişiklerinin saptanmasını sağlayan, etkin ve pratik bir tahmin tekniğidir (Soykan, 2010). Bu yöntem ile, arazi örtüsü ve kullanımındaki değişim ve örtü tiplerindeki sürekliliğin miktarı tahmin edilebilmekte aynı alana ait, farklı zaman dilimlerindeki arazi örtüsü verilerine göre arazi örtüsü kategorileri arasında çapraz tablolama ile geçiş alanları ve geçiş olasılı̆̆ı matrisi hesaplanabilmektedir. Böylece, her bir arazi örtüsü kategorisinin bir sonraki dönem değişimi veya durağanlığı da belirlenmektedir. Geleceğe yönelik arazi örtüsü tahmini yapabilmek için kullanılan Markov Zincirleri modelinin temel prensibi, model derecesine bağlı olarak, herhangi bir zamanda ele alınan bir değerin, kendisinden önceki aynı zaman dilimindeki değerlere bağlı olmasıdır ve tutarlı tahminlerin yapılması, değişkenler ve davranışlara ilişkin birtakım varsayımların gerçekleşmesine bağlıdır (Kurtuluş, 1983). Kısacası, bu modellemeyle geçmiş dönemdeki davranışların gelecekte de devam ettiği düşünülerek tahminlerde bulunulmaktadır. Bu nedenle, doğrusal olmayan ilişkilerin tahmin edilmesinde Markov zincirleri modeli tek başına yetersiz kalabilmektedir (Olmedo ve Mas, 2018). Hücresel Otomat, verilerin hücresel biçimde tanımlar ve her bir hücre komşu hücrelerle ilişkilendirilerek yeni değere sahip hücrelerin oluşturulmasını sağladığı (Yazıcı vd., 2019; Yüzer ve Yüzer, 2006) için doğrusal olmayan ilişkilerin de tahmin edilebilmesi için hücresel otomasyon ve Markov Zincirleri yöntemleri yaygın olarak entegre kullanılmaktadır (Cengiz ve Y1lmaz, 2016; Halmy, vd., 2015; Hamad, vd., 2018; Karip, Bozkaya, ve Göksel, 2017; Mondal, vd., 2013). CA-Markov 
karışık bir yapıya sahip olan zaman ve mekân arasındaki değişimin Coğrafi Bilgi Sistemleri (CBS) tabanında analiz edilerek, özellikle kentsel gelişim, arazi değişimleri gibi süreçleri analiz etmekte kullanılmaktadır (Liu vd., 2005).

Çalışma alanında değerlendirilecek uydu görüntülerinin seçimindeki en önemli faktör Eskişehir'in günümüzdeki görünümünün temellerinin 1980'li yıllara dayanmasıdır. $\mathrm{Bu}$ dönemde yapılan ulaşım yatırımları ile kent içi ulaşımın yönünün belirlenmesi ve hafif raylı sistemin kullanılmaya başlanması söz konusudur. Diğer taraftan sınıflandırmaya uygun en eski görüntünün 1984 yılına ait olmas1 da uydu görüntüsü seçiminde etkili olmuştur. Bu nedenle 1984-2020 y1llarına ait Landsat görüntülerinden yararlanılmıştır (Çizelge 1). Landsat uydu görüntülerinin hücre genişlikleri 30x30'dur. Ayrıca Path=179 Row=32 konumu kullanılmıştır.

Çizelge 1. Kullanılan veri tipleri ve özellikleri

\begin{tabular}{lll}
\hline Tarih & Sensör ve Veri Tipi & Veri Tipi \\
\hline 1984 & Landsat TM 5 & Raster 30m \\
\hline 2020 & Landsat 8 OLI & Raster 30m \\
\hline Kaynak. https://earthexplorer.usgs.gov/
\end{tabular}

Uydu görüntüleri tarihleri seçilirken bulutluluk ve sis durumu göz önüne alınarak yapılacak işlemlerin daha sağlıklı olmasına dikkat edilmiştir. Fakat uydu görüntülerinde az da olsa mevcut olan bulutluluk durumu uydu görüntüsündeki hücre değerlerinin düzeltilmesini gerektirmektedir. $\mathrm{Bu}$ düzeltmeler için Envi 5.3 programı vasıtasıyla radiometrik ve atmosferik düzeltme yapılarak uydu görüntülerinin projeksiyon sistemini coğrafik sistemden metrik sisteme dönüştürülmüştür. Landsat uydu görüntülerinin geometrik düzeltmeleri yapılarak hizmete sunulduğu için geometrik düzeltme uygulanmamıştır. Uydu görüntülerine gerekli düzeltmeler yapıldıktan sonra kontrollü sınıflandırma işlemi için 5 ana sınıf oluşturulmuştur (Mansour vd., 2020; Munthali vd., 2020; Feng vd., 2020; Dewan ve Yamaguchi, 2009) (Çizelge 2).

Çizelge 2. Analizlerde kullanılan 5 arazi sınıfi

\begin{tabular}{lll}
\hline Kod & Kod Açıklama & Açıklama \\
\hline 1 & Kentsel Alan & Kent merkezi \\
\hline 2 & Tarım Alanı & Sulanabilen ve sulanamayan tarım arazileri \\
\hline 3 & Bitki Örtüsü & Orman alanları ve diğer yeşil alanlar \\
\hline 4 & Yol & 1., 2. ve 3. Derece karayolları ve tren yolları \\
\hline 5 & Diğer Alan & Yukarıdaki 4 sınıfa uygun olmayan araziler \\
\hline
\end{tabular}

Kontrollü sınıflandırma yöntemlerinden maximum likelihood kullanılarak 1984 ve 2020 yılları arazi örtüsü sınıfları belirlenmiş ve bitki örtüsü sınıfı ise Normalized Difference Vegetation Index (NDVI) NDVI= (NIR-RED)/(NIR+RED) algoritması uygulanarak elde edilmiştir (Jackson ve Huete, 1991). Radiometrik, atmosferik düzeltmeler, kontrollü sınıflama ve NDVI algoritması uygulandıktan sonra elde edilen raster veriler, vektör verilere dönüştürülerek yersel kontrollerle (uydu görüntüsü, topografik haritalar vs.) düzeltilmiş ve arazi örtüsü sınıfları son halini almıştır. 
Elde edilen vektör veriler ArcGIS 10.6.1 programı ile siniflandırmaya uygun olarak 10x10 hücresel boyutta CA-Markov Zincirleri analizi için uygun raster veriye dönüştürülmüştür. 1984 ve 2020 yıllarına ait kontrollü sınıflandırılma uygulanmış raster veriler ile yersel düzeltmelerle tekrar oluşturulmuş raster veriler arasındaki uyumun belirlenmesi için kappa istatistiği analizi kullanılmıştır. Kappa istatistiği raster veriler arasındaki uyumun belirlenmesi için tercih edilen yöntemlerden biridir (Cohen, 1960). Bu istatistikle 1984 ve 2020 yıllarına ait kontrollü sınıflandırma yöntemiyle elde edilen raster veriler ile yersel kontrollerle düzeltilmiş raster veriler arasındaki uyum matematiksel olarak ortaya konulmuştur (Çizelge 3 ve Çizelge 4). 1984 yılı kontrollü sınıflandırma uygulanmış raster veri ile yersel kontrollerle düzeltmeleri yapılarak elde edilmiş raster verinin uyum oranı 0.654365 olarak tespit edilmiştir (Çizelge 3). 2020 y1lı kontrollü sınıflandırma uygulanmış raster veri ile yersel kontrollerle düzeltmeleri yapılarak elde edilmiş raster verinin uyumu ise 0.715453 olarak tespit edilmiştir (Çizelge 4). Her iki değer de 1'e yaklaştığından Kappa istatistiği matematiksel olarak uyumlu sonuç vermiştir.

Çizelge 3. 1984 raster verilerinin Kappa istatistik analizi

\begin{tabular}{|c|c|c|c|c|c|c|c|}
\hline \multicolumn{8}{|c|}{$\begin{array}{l}\text { Hata Matrix Analizi: } 1984 \text { Kontrollü Sınıflandırma (Sütunlar: Gerçek) ile } \\
1984 \text { Düzeltilmiş Verinin (Satır: Eşleştirme) Karşılaştırılması }\end{array}$} \\
\hline & (1) Kentsel Alan & (2) Tarım Alanı & (3) Bitki Örtüsü & (4) Yol & (5) Diğger Alan & Toplam & HataC \\
\hline (1) Kentsel Alan & 38467 & 4196 & 52 & 4241 & 3446 & 50402 & 0,236796 \\
\hline (2) Tarım Alanı & 9052 & 223979 & 2903 & 4605 & 51709 & 292248 & 0,233600 \\
\hline (3) Bitki Örtüsü & 13 & 17 & 8406 & 0 & 238 & 8674 & 0,030897 \\
\hline (4) Yol & 1233 & 2585 & 158 & 886 & 1095 & 5957 & 0,851267 \\
\hline (5) Diğer Alan & 2056 & 9362 & 2032 & 942 & 112327 & 126719 & 0,113574 \\
\hline Toplam & 50821 & 240193 & 13551 & 10674 & 168815 & 484000 & \\
\hline Hata O & 0,243088 & 0,067294 & 0,379677 & 0,916995 & 0,334615 & & 0,206477 \\
\hline \multicolumn{5}{|c|}{$\begin{array}{l}\text { Hata O: Hata = İhmal Hataları (oranlar olarak ifade edilir). } \\
\text { Hata C: Komisyon Hataları (oranlar olarak ifade edilir). } \\
90 \% \text { Güven Aralığ } 1=+/-0.000957(0.205520-0.207434) \\
95 \% \text { Güven Aralığ1 }=+/-0.001140(0.205337-0.207618) \\
99 \% \text { Güven Aralığ } 1=+/-0.001501(0.204976-0.207978)\end{array}$} & \multicolumn{3}{|c|}{ Genel Kappa: 0.654365} \\
\hline
\end{tabular}


Çizelge 4. 2020 raster verilerinin Kappa istatistik analizi

\begin{tabular}{|c|c|c|c|c|c|c|c|}
\hline \multicolumn{8}{|c|}{$\begin{array}{l}\text { Hata Matrix Analizi: } 2020 \text { Kontrollü Sınıflandırma (Sütunlar: Gerçek) ile } \\
2020 \text { Düzeltilmiş Verinin (Satır: Eşleştirme) Karşılaştırılması }\end{array}$} \\
\hline & (1) Kentsel Alan & (2) Tarım Alanı & (3) Bitki Örtüsü & (4) Yol & (5) Diğer Alan & Toplam & HataC \\
\hline (1) Kentsel Alan & 87380 & 9982 & 528 & 8885 & 11584 & 118359 & 0,261738 \\
\hline (2) Tarım Alanı & 8861 & 228930 & 930 & 3122 & 25753 & 267596 & 0,144494 \\
\hline (3) Bitki Örtüsü & 301 & 106 & 9470 & 10 & 140 & 10027 & 0,055550 \\
\hline (4) Yol & 3835 & 3788 & 144 & 1286 & 1284 & 10337 & 0,875593 \\
\hline (5) Diğer Alan & 1817 & 3086 & 1343 & 1291 & 70144 & 77681 & 0,097025 \\
\hline Toplam & 102194 & 245892 & 12415 & 14594 & 108905 & 484000 & \\
\hline Hata $\mathrm{O}$ & 0,144960 & 0,068982 & 0,237213 & 0,911882 & 0,355916 & & 0,179318 \\
\hline $\begin{array}{l}\text { Hata O: Hata }=\text { İh } \\
\text { Hata C: Komisyo } \\
\text { 90\% Güven Aralı } \\
\text { 95\% Güven Aral } \\
\text { 99\% Güven Arall }\end{array}$ & $\begin{array}{l}\text { Imal Hataları (oranl } \\
\mathrm{n} \text { Hatalar (oranlar } \\
\breve{g}_{1}=+/-0.000957( \\
\breve{g}_{1}=+/-0.001140( \\
\breve{g}_{1}=+/-0.001501\end{array}$ & $\begin{array}{c}\text { lar olarak ifade edi } \\
\text { olarak ifade edilir) } \\
(0.205520-0.207 \\
0.205337-0.207 \\
0.204976-0.207\end{array}$ & $\begin{array}{l}\text { ilir). } \\
\text {. } \\
434) \\
618) \\
978)\end{array}$ & & \multicolumn{3}{|c|}{ Genel Kappa: 0.715453} \\
\hline
\end{tabular}

Doğruluğu onaylanan raster veriler, Terrset 18.1 programı ile .tiff formatından .rst formatına dönüştürülmüş ve belirlenen 5 sinıfa göre 1 ile 5 arasında değerler verilerek rakamsal olarak yeniden sınıflandırılmıştır. $\mathrm{Bu}$ işlemlerden sonra Markov Zincirleri analizine uygun hale getirilen verilere Markov Zincirleri analizi uygulanmıştır. Markov Zincirleri analizi ile 2056 yılına ait arazi sınıflarının istatiksel değişim oranları tablosu oluşturulmuş ve değişim oranları tablosu yardımıyla 2020 yılına ait raster verisine CA-Markov uygulanarak 2056 tahmin haritası üretilmiştir. Üretilen bu haritadan alan ve yüzde değerlerinin hesaplanması için 1984, 2020 ve 2056 yıllarına ait 10x10 hücresel boyuta sahip olan raster veriler vektör veriye dönüştürülmüştür (Şekil 2). Ayrıca kentsel alanının hangi yöne doğru geliştiğini ortaya koyabilmek için çalışma alanı Kuzeybatı, Kuzeydoğu, Güneydoğu ve Güneybatı yönlerinde ayrıntılı olarak incelenmiştir. 


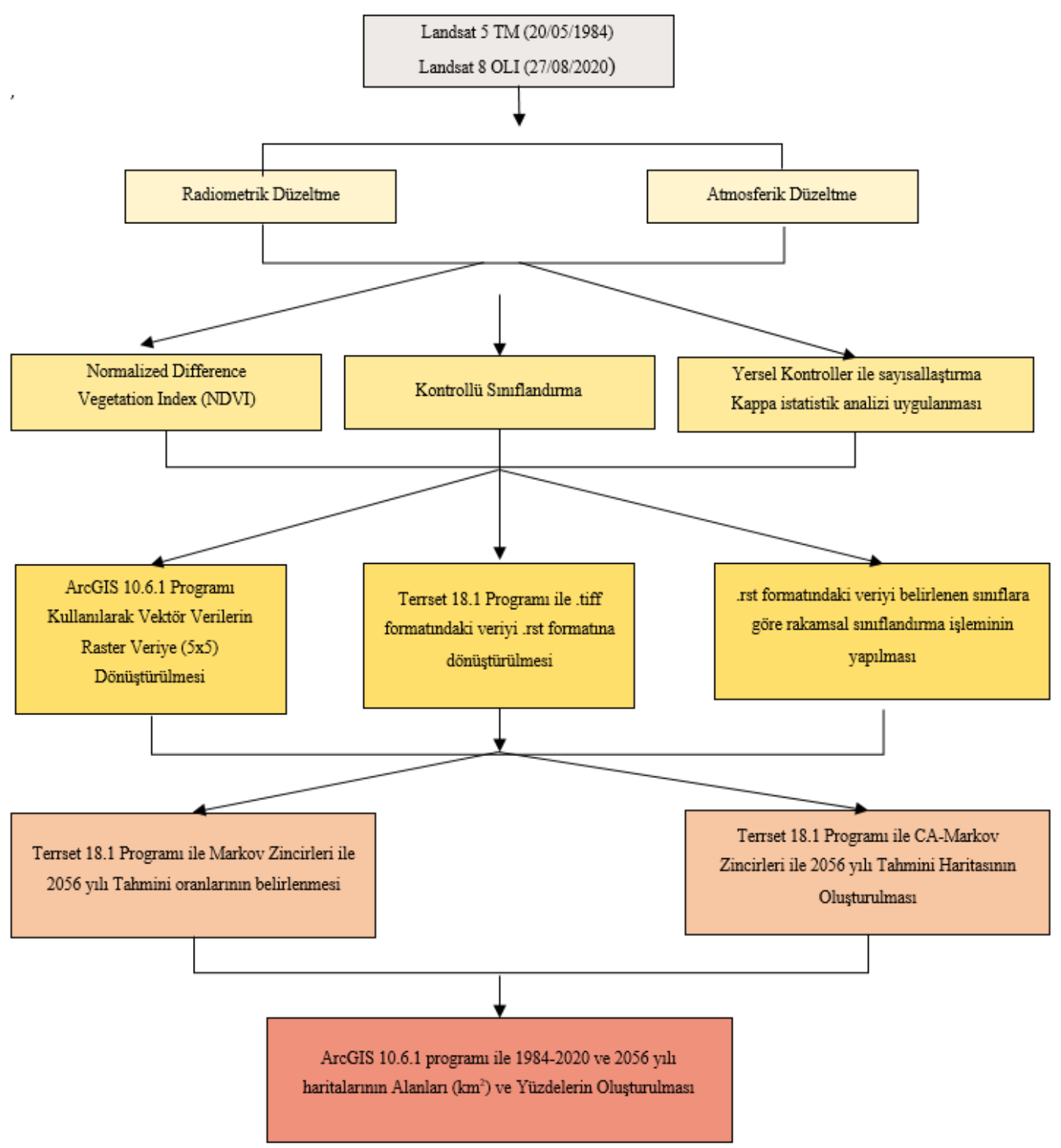

Şekil 2. Çalışmada kullanılan yöntem şeması

\section{Bulgular}

Eskişehir'in kentsel büyüme alanındaki değişimi tespit edebilmek için uydu görüntülerinden üretilen arazi örtüsü sınıfları, başlangıç yılı olarak belirlenen 1984, günümüzdeki durumu gösteren 2020 ve projeksiyon tahmin yılı olarak 2056 yılları için ayrı ayrı analiz edilmiştir.

Daha önce belirlenen 5 arazi örtüsü sınıfı kapsamında yapılan analize göre, 1984 yılında Eskişehir'in kentsel alanı tarım alanları ile çevrelenmiş bir yapıdadır. Tek merkezli bir özellik gösteren Eskişehir'in bu dönemdeki yayılım alanı Ankara-Eskişehir, Eskişehir-Bursa karayolları ve yakın çevresindeki sanayi alanlarına bağlı olarak kuzeybatı-güneydoğu doğrultusunda gelişme göstermiş̧ir (Şekil 3). 


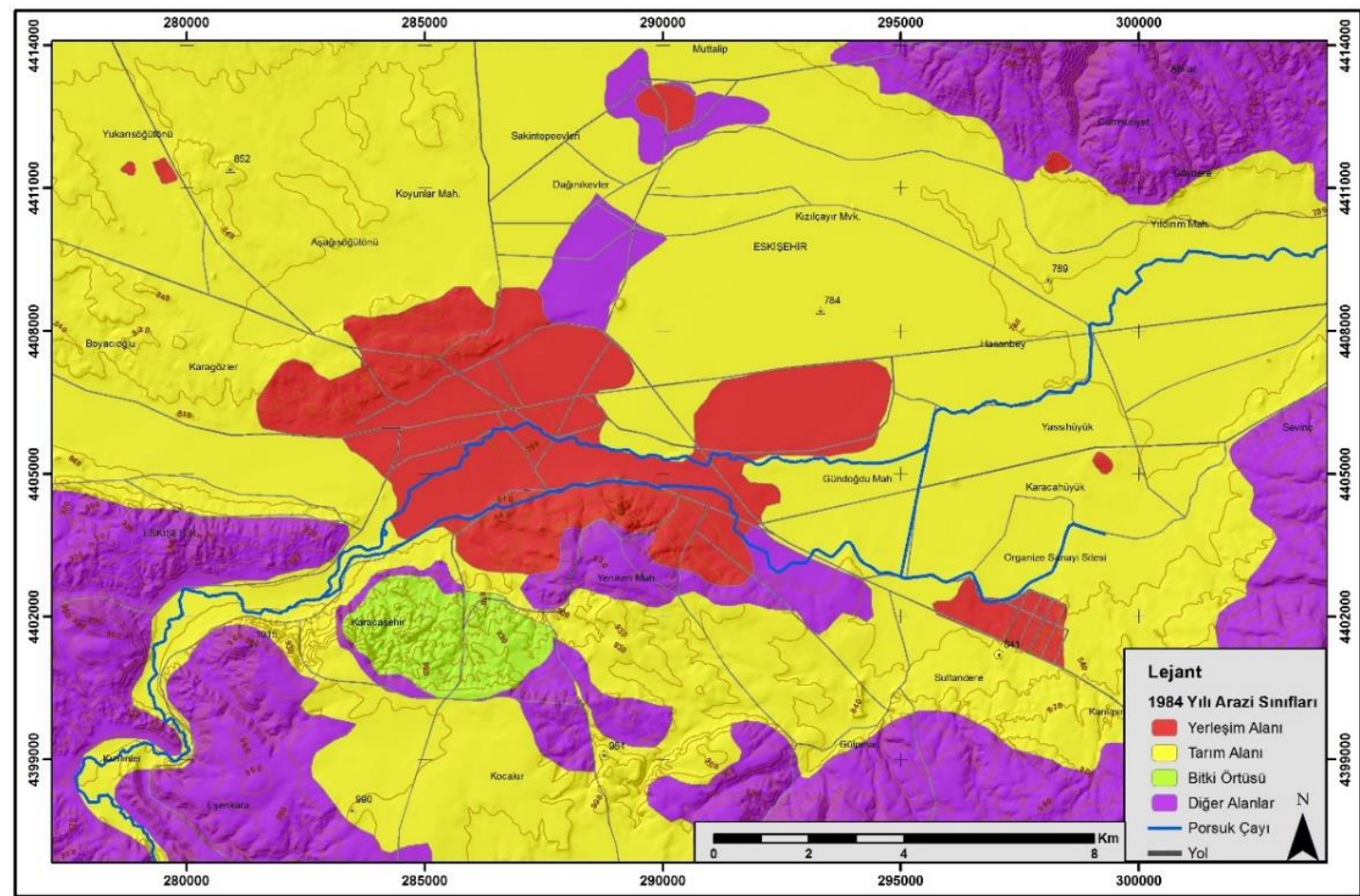

Şekil 3. 1984 yılı arazi örtüsü sınıfları haritası

2020 yılında Eskişehir kentsel alanı hızla büyüyerek kuzey-güney aksinde de gelişme göstermeye başlamış bu yayılma özellikle kent çevresindeki tarım alanları üzerinde görülmüştür (Şekil 4). Kentsel büyüme tek merkezlilikten çok merkezliliğe doğru evrilmiş ve kent merkezi lekesinden ayrı küçük kentsel lekeler ortaya çıkmıştır. Kentlerde artan tüketim mekânlarının en önemli örneği olan AVM'ler 2000'li yıllardan sonra Eskişehir'de de artış göstermiştir. 2007 yılında kurulan Kanatlı Alışveriş Merkezi de kentsel büyümeye yön vermiştir. AVM çevrelerinde gerçekleştirilen dönüşüm projeleri ile kent parçalar halinde büyümeye devam etmiştir. Kentsel büyümenin evrilmesinde Eskişehir'in 2013 yılında Türk Kültür Başkenti ilan edilmesinin de rolü olmuştur. İç turizme yönelik olarak yenilenen tarihi yapıların bulunduğu Odunpazarı, Kurtuluş Müzesi ve Haller Gençlik Merkezi; yapılı çevre olarak tasarlanan Kentpark, Sazova Bilim Sanat ve Kültür Parkı, Bilim Deney Merkezi ve Sualtı Dünyası gibi mekânlar; çevresel kalitenin arttırılmasına yönelik düzenlenen Porsuk Çayı ve etrafı ile Eskişehir kentsel turizm kaynaklarında nitelik ve nicelik bakımından önemli gelişmelere sahne olmuş kentin büyüme hızı ve yönüne doğrudan katkı sağlamıştır. 


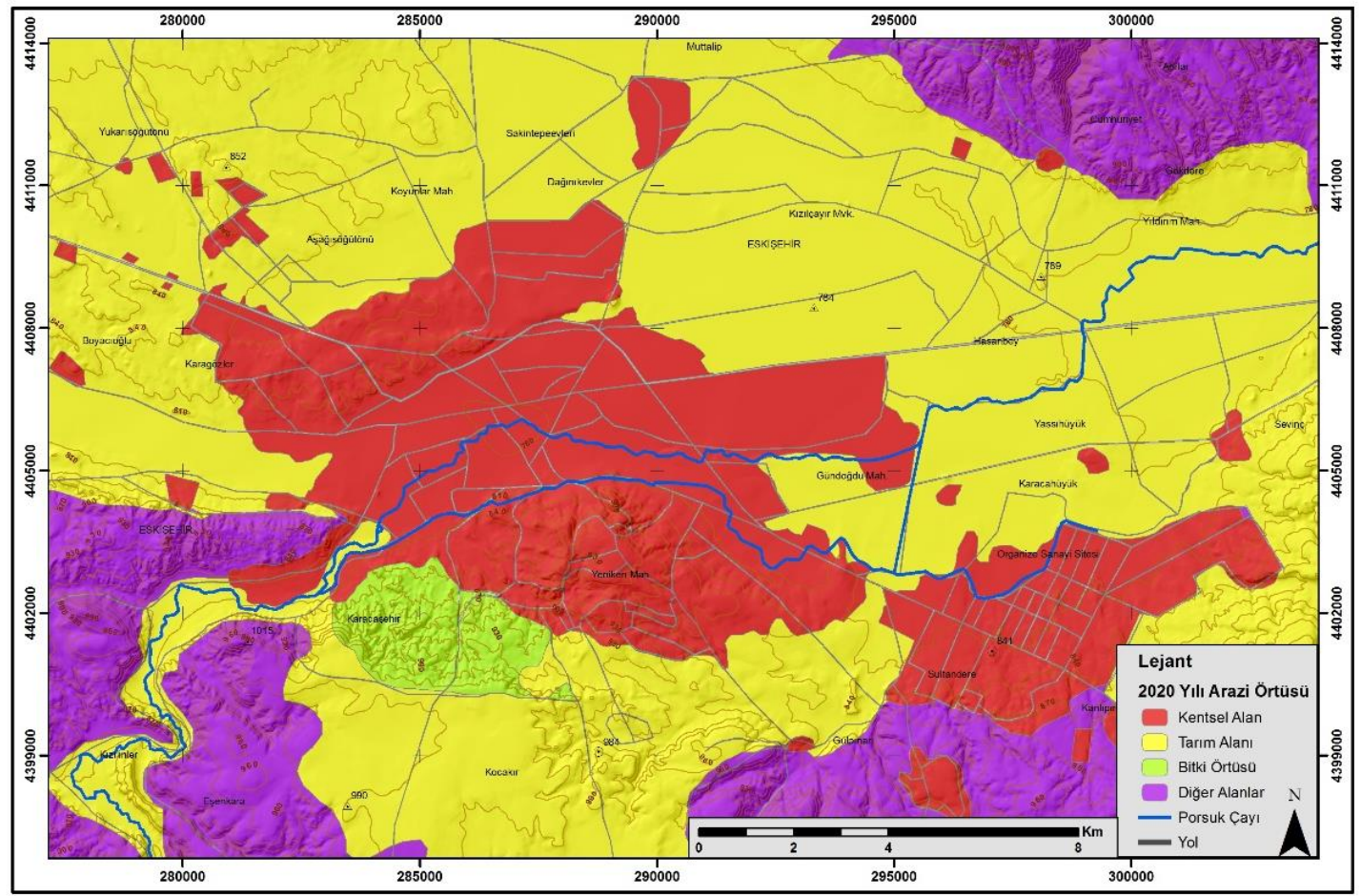

Şekil 4. 2020 yılı arazi örtüsü sınıfları haritası

1984-2020 yılları için tespit edilen arazi örtüsü sınıfları için Markov Zincirleri kullanılmış ve değişim oranları hesaplanmıştır (Çizelge 5). Buna göre, 1984 yılında tarım arazisi olan alanların 2020 y1lında \%24 ile kentsel alana; 1984 yılında diğer alan sınıfının 2020 yılında \%12 ile kentsel alana dönüştüğü gözlenmiştir. Bu durum Eskişehir kent alanının tarım ve diğer alanlar üzerinde yayıldığının bir göstergesi olmuştur.

Çizelge 5. 1984-2020 yılları arasındaki Markov değişim oranları (\%)

\begin{tabular}{|c|c|c|c|c|c|c|}
\hline \multirow{2}{*}{\multicolumn{2}{|c|}{$\begin{array}{l}\text { 1984-2020 Yılları Arasındaki } \\
\text { Markov Değişim Oranları (\%) }\end{array}$}} & \multicolumn{5}{|c|}{$2020 \mathrm{Y}_{1} \mathrm{l}_{1}$} \\
\hline & & $\begin{array}{l}\text { (1) Kentsel } \\
\text { Alan }\end{array}$ & \multirow{2}{*}{$\begin{array}{r}\text { (2) Tarım } \\
\text { Alanı } \\
0,00\end{array}$} & \multirow{2}{*}{$\begin{array}{r}\text { (3) Bitki } \\
\text { Örtüsü } \\
0,00\end{array}$} & \multirow{2}{*}{$\begin{array}{r}\text { (4) Yol } \\
0,11\end{array}$} & \multirow{2}{*}{$\begin{array}{r}\text { (5) Diğer } \\
\text { Alan } \\
0,00\end{array}$} \\
\hline \multirow{5}{*}{$\begin{array}{l}\exists \\
\Xi \\
\stackrel{\searrow}{\Xi}\end{array}$} & (1) Kentsel Alan & 0,89 & & & & \\
\hline & (2) Tarım Alanı & 0,24 & 0,72 & 0,00 & 0,01 & 0,02 \\
\hline & (3) Bitki Örtüsü & 0,06 & 0,04 & 0,88 & 0,02 & 0,00 \\
\hline & (4) Yol & 0,02 & 0,03 & 0,00 & 0,90 & 0,00 \\
\hline & (5) Diğer Alan & 0,12 & 0,31 & 0,01 & 0,01 & 0,55 \\
\hline
\end{tabular}

Araştırma alanındaki 1984 ve 2020 yıllarına ait arazi örtüsü verileri Terrset 18.1 programı ile değerlendirilerek, 2056 yılında kent alanının ve arazi örtüsünün nasıl değişeceği tahmin edilmiştir. Markov Zincirleriyle elde edilen değişim oranları tablosu ile Hücresel Otomat-Markov Zincirleri (CAMarkov) uygulanarak 2056 yılı arazi örtüsü sınıfları haritası elde edilmiştir (Şekil 5). 


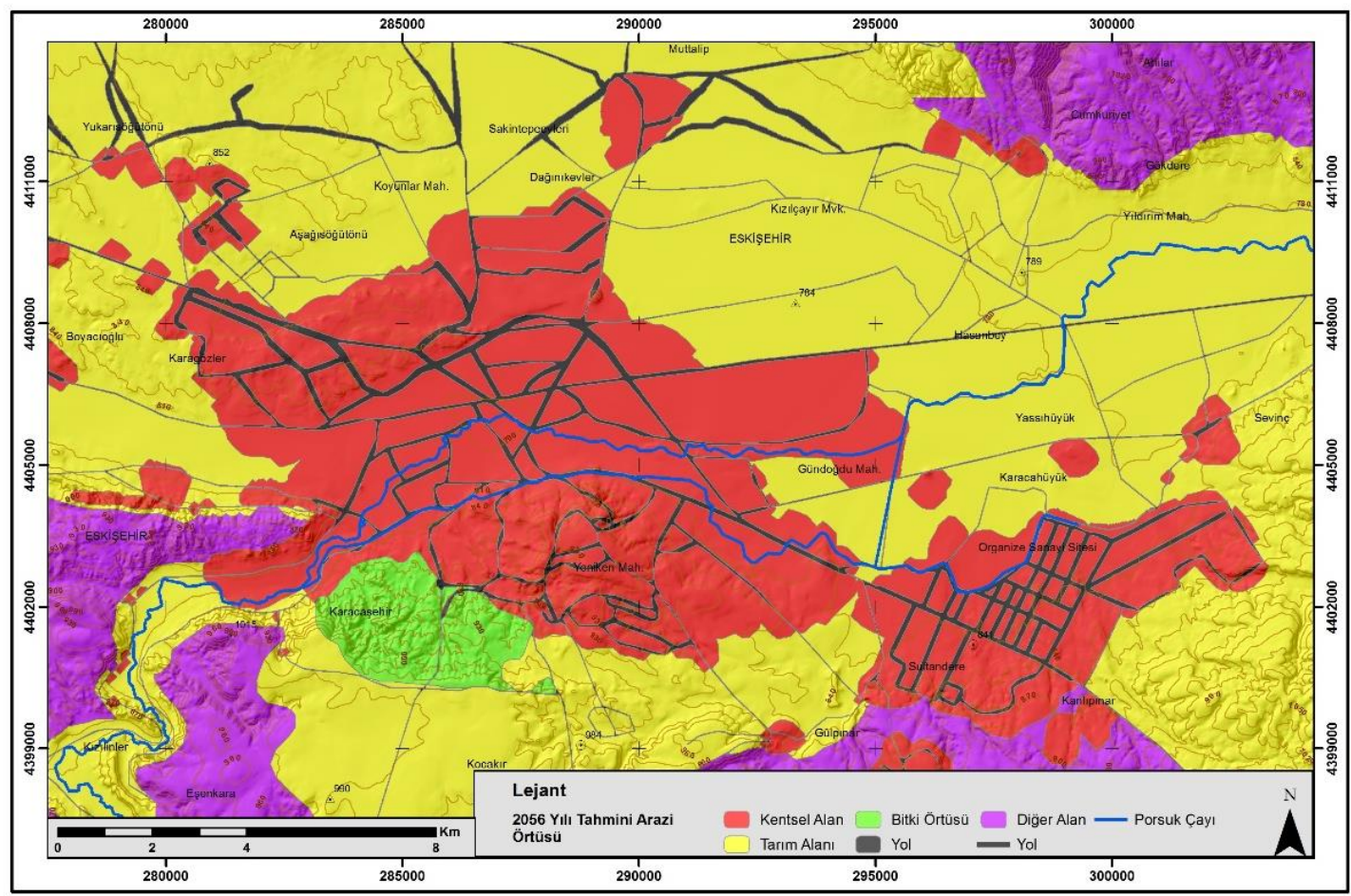

Şekil 5. 2056 yılı arazi örtüsü sınıfları haritası

1984, 2020 ve 2056 (tahmin) yıllarına ait arazi örtüsü sınıflarının alan ve yüzde cinsinden değerleri incelendiğinde en dikkat çekici artışın yollarda gerçekleşeceği görülmektedir (Çizelge 5 ve 6). Kentsel alanın genişlemesi ve buna bağlı olarak ulaşım ihtiyacının artması yolların alansal olarak en fazla artan sınıf olmasına neden olacaktır. Oransal olarak değerlendirildiğinde bu durum çok daha açık olarak görünmektedir. Nitekim, 1984-2020 yılları arasında \%0.86 oranında artış gösteren yol sınıfı 2020-2056 yılları arasında \%3.25 oranında artacaktır.

Çizelge 6. 1984- 2020 ve 2056 yıllarına ait arazi örtüsü sınıflarının alansal değişimi $\left(\mathrm{km}^{2}\right)$

\begin{tabular}{llccc}
\hline Kod & Kod Açıklama & 1984 Yılı Toplam Alan $\left(\mathrm{km}^{2}\right)$ & 2020 Yılı Toplam Alan $\left(\mathrm{km}^{2}\right)$ & 2056 Yllı Tahmini $\left(\mathrm{km}^{2}\right)$ \\
\hline 1 & Kentsel Alan & 45,34 & 106,83 & 117,67 \\
\hline 2 & Tarım Alanı & 283,23 & 263,41 & 253,23 \\
\hline 3 & Bitki Örüsü & 7,82 & 9,05 & 8,95 \\
\hline 4 & Yol & 5,59 & 9,68 & 25,15 \\
\hline 5 & Diğer Alan & 133,85 & 86,86 & 70,66 \\
\hline
\end{tabular}

Aynı şekilde, Eskişehir kentsel alanında 1984 yılından 2020 yılına kadar \%12.92'lik bir büyüme gerçekleşmişken, 2020-2056 yılları arasında \%2.29'luk bir büyüme öngörülmektedir. Bu verilerden yola çıkarak kentleşmenin alansal büyüme hızının yavaşlayacağını ve farklı kentsel merkezlerin zamanla birleşerek tek bir kentsel alanı oluşturacağını söylemek mümkündür. Tarım alanlarında ise dönemler arasında düzenli bir azalma gözlenmektedir. Bu azalma oransal olarak 1984-2020 yılları arasında \%4.16 iken, 2020-2056 yılları arasında \%2.12 olacaktır. Bu durum, kent merkezi çevresinde yer alan tarım alanlarının şehirleşme baskı altında kalamaya devam edeceğinin bir göstergesidir. Bitki örtüsünde ise 1984-2020 yılları arasında \%0.26'lık artış söz konusu iken, 2020-2056 yılları arasın \%0.02'lik bir düşüş 
söz konusu olacaktır. 1984-2020 yılları arasında diğer alanlarda \%9.88'lik bir azalma vardır. 2020-2056 döneminde bu azalma \%3.4 oranına düşecektir (Çizelge 5,6; Şekil 6).

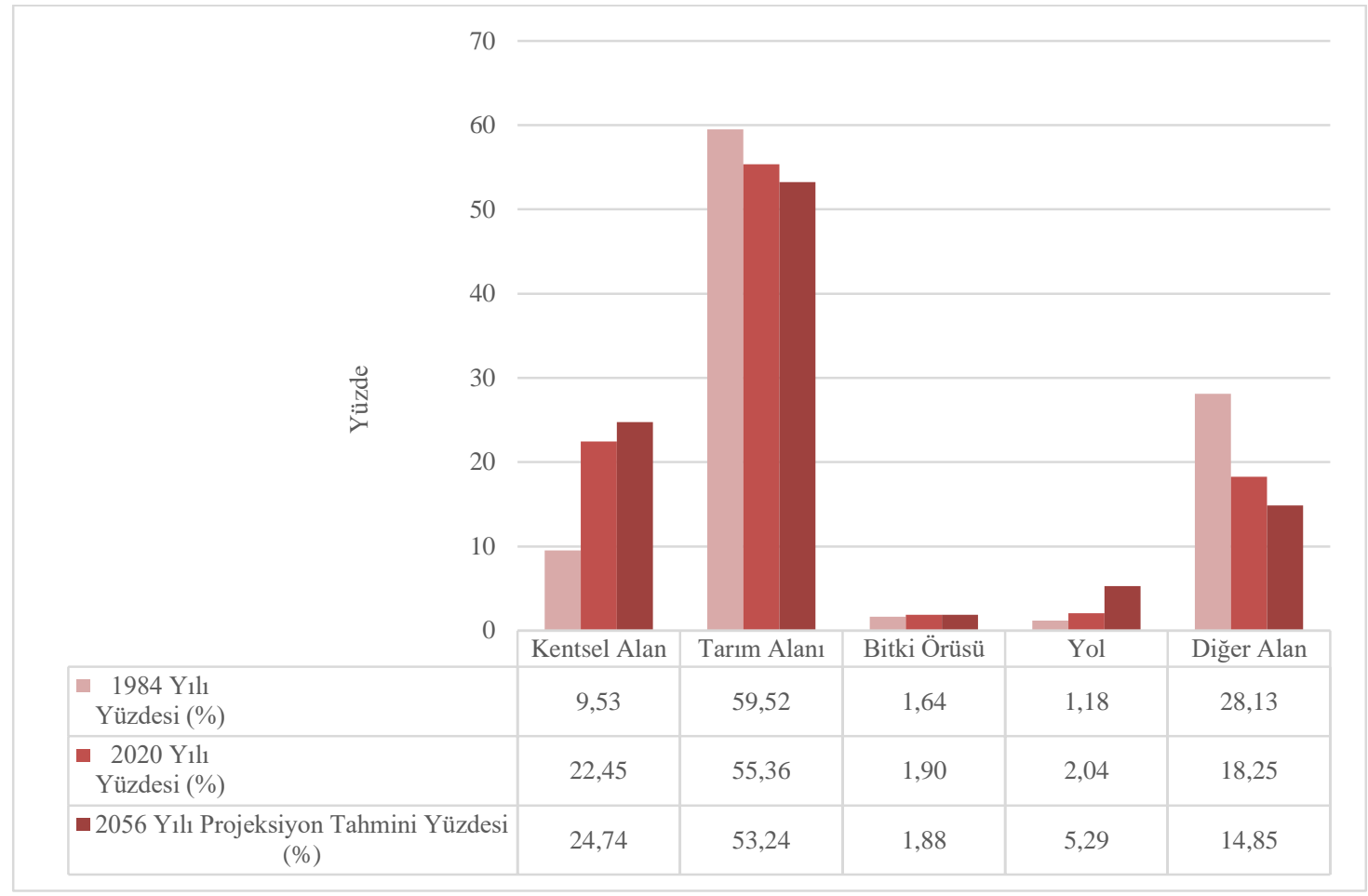

Şekil 6. 1984, 2020 ve 2056 yıllarına ait arazi örtüsü sınıfları yüzde değişim grafiğgi

\section{Tartışma ve Sonuç}

Hücresel Otomat ve CA-Markov modellerini kullanarak, Eskişehir kentsel büyüme alanının nasıl ve ne yönde gelişeceğini tahmin etmek amacıyla yapılan bu çalışma, kentin gelecekteki görünümü hakkında bir çerçeve sunmaktadır. Bu kapsamda ilk olarak 1984-2020 tarihleri arasındaki değişimin CA-Markov ile analiz edilmesi ve bu bulgulardan yola çıkarak 2056 yılındaki görünümü tespit edilmiştir. Çalışmanın sonuçları değerlendirildiğinde, kentsel büyüme süreçlerinin anlaşılması için CBS ve Uzaktan Algılama yöntemlerinin önemi ortaya çıkmaktadır. Eskişehir'in, Türkiye'nin kentleşme tarihi ile uyumlu bir kentsel büyüme sürecine sahip olması, çalışmanın bulgularının Türkiye'deki diğer kentler için de bir öngörü olarak değerlendirilebilmesine imkân tanımaktadır.

Eskişehir, başlangıç yılı kabul edilen 1984 yılından 2020 yılına kadar geçen süreçte alansal olarak yaklaşık 2 katı (2.3) büyümüştür. Elde edilen tahmin haritasına göre önümüzdeki 36 yılda Eskişehir' in kentsel büyümesi nispeten yavaşlayacak ve çok merkezli odaklar zamanla birleşecektir. Nitekim, 2056 yılında Eskişehir kentsel alanının etrafında yer alan küçük lekelerin daha çok kuzeybatı yönünde gelişeceği öngörülmüştür (Şekil 7).

Kentsel büyümenin yönü ulaşım aksıyla uyumlu olarak kuzeybat1-güneydoğu doğrultusunda olacaktır. Diğer taraftan sanayi bölgesinin kentin güneydoğusunda yer alması, büyümenin bu doğrultuda devam edeceğini göstermektedir (Çizelge 7, Şekil 7, Şekil 8). 
Çizelge 7. 1984-2020 yılları arasındaki kentsel alan değişim değerleri $\left(\mathrm{km}^{2}\right)$

\begin{tabular}{llll}
\hline Kentsel Alan $\left(\mathrm{km}^{2}\right)$ & $\begin{array}{l}\text { 1984 Y1lı Toplam Alan } \\
\left(\mathrm{km}^{2}\right)\end{array}$ & $\begin{array}{l}\text { 2020 Yllı Toplam } \\
\text { Alan }\left(\mathrm{km}^{2}\right)\end{array}$ & $\begin{array}{l}\text { 2056 Y1lı Projeksiyon } \\
\text { Tahmini }\left(\mathrm{km}^{2}\right)\end{array}$ \\
\hline Kuzeybatı & 20,05 & 38,05 & 39,5 \\
\hline Kuzeydoğu & 7,02 & 9,11 & 10,96 \\
\hline Güneydoğu & 6,05 & 33,94 & 39,22 \\
\hline Güneybatı & 12,22 & 27,73 & 27,99 \\
\hline
\end{tabular}

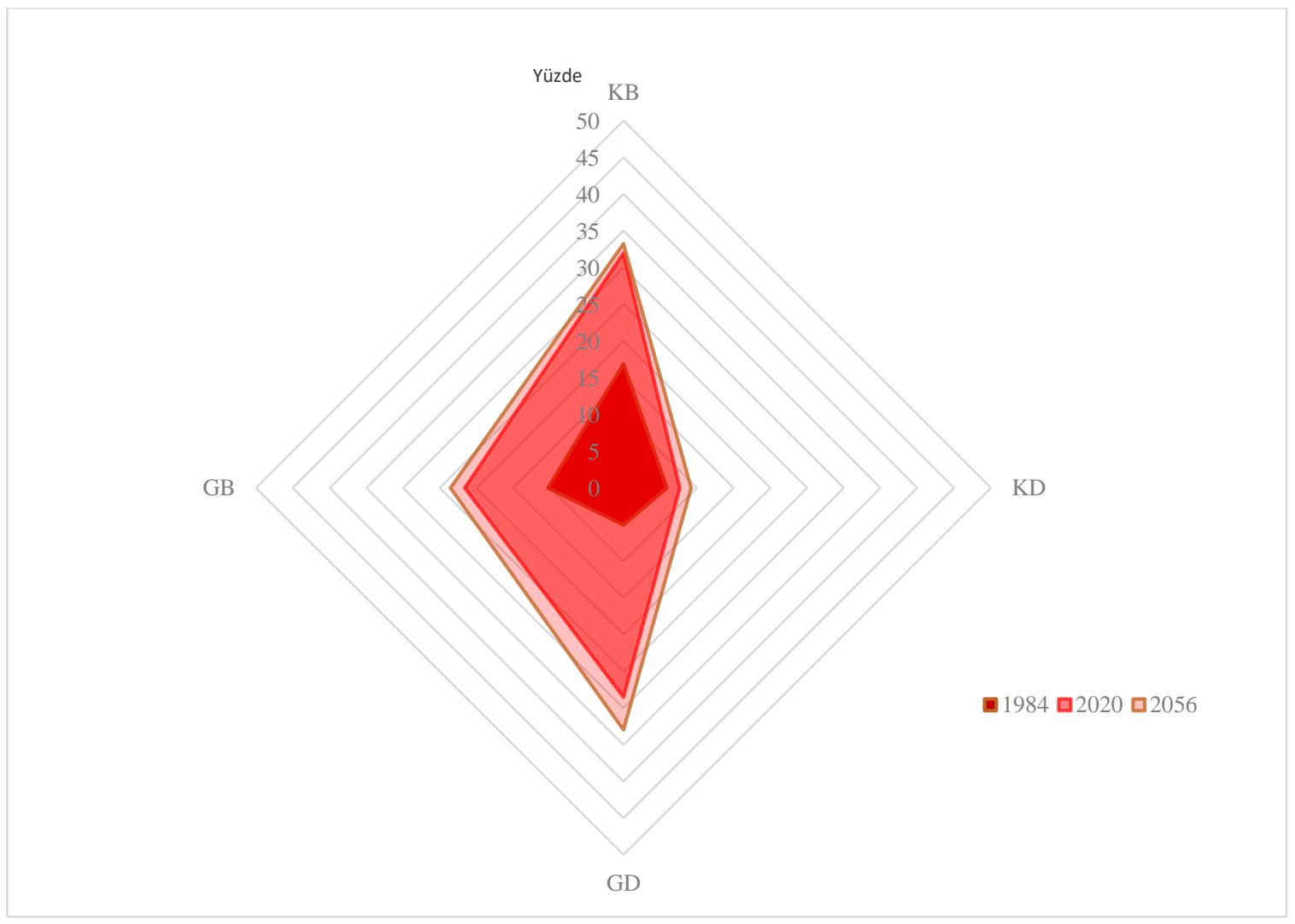

Şekil 7. 1984, 2020 ve 2056 yıllarında Eskişehir kentsel alanının büyüme yönü (\%)

1984 yılında İstanbul-Ankara metropolleri arasında yer alan ulaşım aksı üzerinde kabaca doğubatı doğrultusunda gerçekleşen büyüme, OSB'nin büyümesine bağlı olarak 2020 yılında kuzey-güney yönde de hız kazanmıştır. 2056 projeksiyonunda ise büyümenin mevcut durumla uyumlu olarak devam edeceği ve kent merkezinden ayrı büyüyen kentsel lekelerin zamanla birleşerek bir bütünü oluşturacağı öngörülmektedir (Şekil 8). 


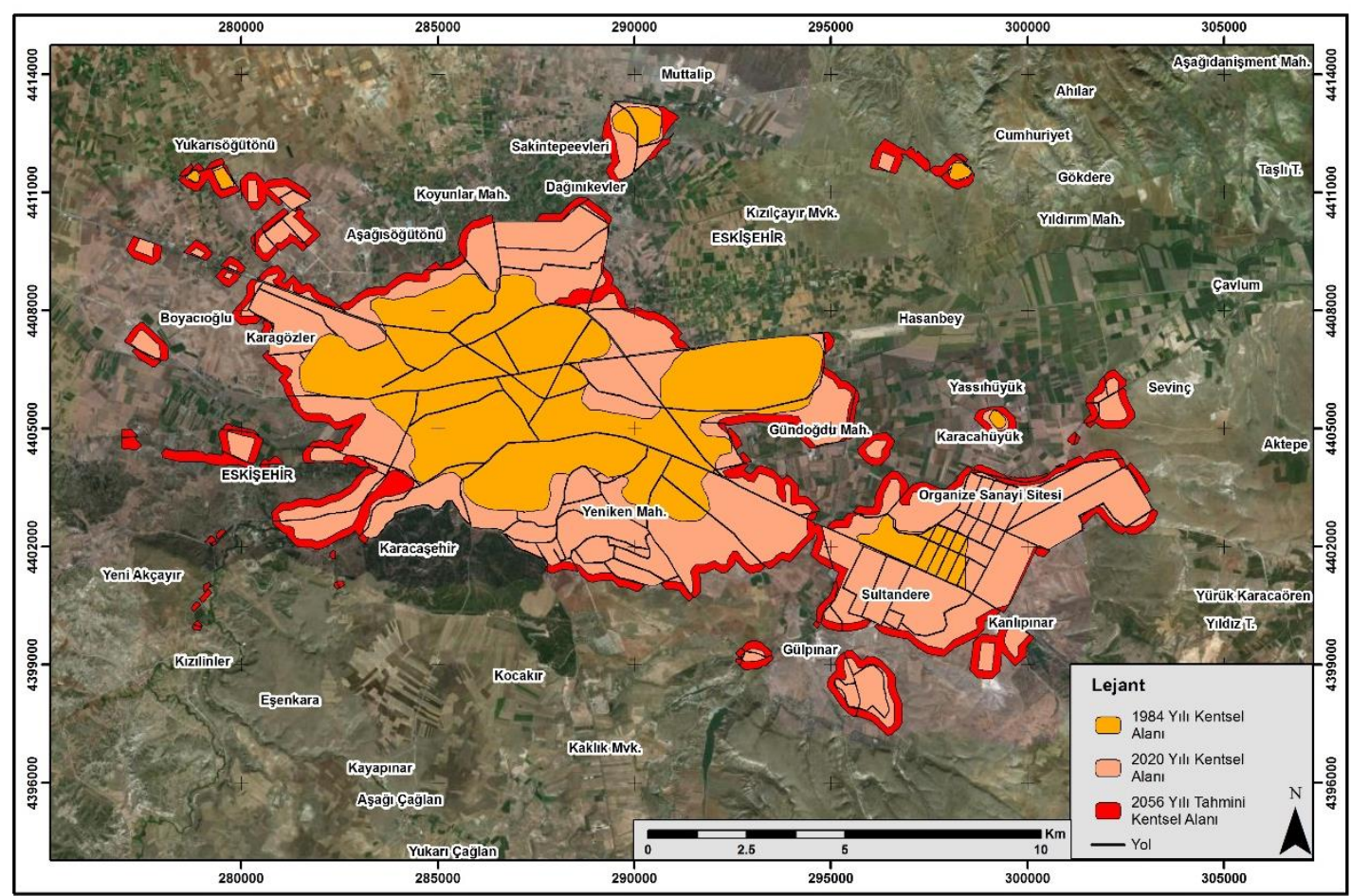

Şekil 8. 1984, 2020 ve 2056 yıllarına ait kentsel büyüme haritas1

Eskişehir için yapılan bir kentsel büyüme senaryosunun, başta kent plancıları olmak üzere, tüm karar alıcılara fayda sağlaması beklenmektedir. Farklı yıllarda kentin tarım, bitki örtüsü, yol ve en önemlisi kentsel alan kapsamında ayrı ayrı değerlendirilerek değişikliklerin analiz edilmesi ve yorumlanması, kentin gelecekte göstereceği gelişimin de öngörülmesini mümkün kılmıştır. Eskişehir'deki mevcut kentsel büyümeyi yönlendiren en önemli göstergeler; sanayi yatırımları, yol ağı, kentsel dönüşüm projeleri, iç turizme yönelik yenilenen bölgeler ve tüketim mekânlarının konumu ile olmuştur. Bu bağlamda kentin gelişiminde gerek yerel devlet politikaları, gerekse serbest piyasanın etkili olduğu söylenebilir. Bu çalışmanın bulgularına göre kentin gelecekteki durumunun göz önüne alınarak planlı ve etkili kentsel stratejilerin geliştirilmesi önerilmektedir. 

CA-Markov Chains (1984-2056)

\author{
Ersin Ateş ${ }^{\mathrm{a}}$, Merve Altundal Öncü ${ }^{\mathrm{a}}$, Rüya Bayar*b, Mutlu Yılmaz
}

\title{
EXTENDED ABSTRACT
}

\section{Introduction}

Considering that urban growth has many dimensions and creates spatial usage changes over time; the fact that cities have different urbanization dynamics, develop at different speeds and display different land cover characteristics cause the differentiation of their spreading areas and the problems they have. For this reason, determining the temporal change of the urban area and making predictions for the future has an important place in planning and decision-making processes. Finding solutions by developing measures for urban problems depends on predicting how much the urban areas will grow in which direction. For this reason, determining the temporal change of the urban area and making predictions for the future have an important place in planning and decision-making processes.

Geographic Information Systems (GIS) and Remote Sensing-based simulation models have come to the fore in the studies prepared in the last 10 years within the scope of land cover changes, spatial processes and future predictions (Alan et al., 2020; Aydın, 2011; Canpolat and Dağl1, 2020; Cengiz and Y1lmaz, 2016; Halmy et al., 2015; Hamad et al., 2018; Iacona et al., 2012; Karip Bozkaya and Göksel, 2017; Mammadov et al., 2019; Sang et al., 2011). With simulation models, natural and human factors that affect the diversity of land cover are included in the system analysis as inputs and these are explained by estimating space as output (Canpolat and Dağl1, 2020). The most prominent of these methods and the one used in this study is the CA-Markov model. This model differs from the others due to the high quality of the predictions it offers (Mas et al., 2014).

This study aims to predict the future state of Eskişehir urban area by integrating the Cellular Automat and Markov Chains models. In this context, taking into account the growth of Eskişehir urban area between 1984-2020, Eskişehir urban area in 2056 has been estimated.

\footnotetext{
* Corresponding Author: rbayar@ankara.edu.tr

a Ankara University, Vocational School of Ayaş, Department of Architecture and Urban Planning, Ankara/Turkey, http://orcid.org/ 0000-0003-2402-9134

a Ankara University, Vocational School of Ayaş, Department of Architecture and Urban Planning, Ankara/Turkey, http://orcid.org/ 0000-0002-1956-2017

b Ankara University, Faculty of Language, History and Geography, Geography Department, Ankara/Turkey, http://orcid.org/ 0000-0003-3115-3707

${ }^{\mathrm{b}}$ Ankara University, Faculty of Language, History and Geography, Geography Department, Ankara/Turkey, http://orcid.org/ 0000-0001-8914-1165
} 


\section{Methodology}

Cellular Automat defines the data in a cellular form and enables the creation of cells with new value by associating each cell with neighboring cells (Yazıcı et al., 2019; Yüzer and Yüzer, 2006). (Cengiz and Y1lmaz, 2016; Halmy, et al., 2015; Hamad, et al., 2018; Karip, Bozkaya, and Göksel, 2017; Mondala, et al., 2013). CA-Markov, on the other hand, is used to analyze processes such as urban development and land changes by analyzing the change between time and space, which has a mixed structure, on the basis of Geographical Information Systems (GIS) (Liu et al., 2005). The CA-Markov model makes predictions for the future by analyzing the table and pixel data obtained from Markov chains and presents this data as a visual output. The model can distinguish between different land cover classes as well as determine the rate of transition between classes and predict their future situations (Behera et al., 2012; Çağlıyan and Dağl1, 2015; Houet and Hubert, 2006; Muller and Middleton, 1994). After making the necessary corrections to the satellite images, 5 main classes were created for the controlled classification process (Dewan and Yamaguchi, 2009; Feng et al., 2020; Mansour et al., 2020; Munthali et al., 2020). The year land cover classes were determined and the vegetation class was obtained by applying the Normalized Difference Vegetation Index (NDVI) NDVI = (NIR-RED) / (NIR + RED) algorithm (Jackson and Huete, 1991). The vector data obtained from ArcGIS 10.6.1. Kappa statistical analysis was used to determine the harmony between raster data with controlled classification of 1984 and 2020 and raster data reconstructed with local corrections. Converting from tiff format to .rst format with Terrset 18.1 program it was reclassified numerically by giving values between 1 and 5 according to the specified 5 classes. After these processes, Markov Chains analysis was applied to the data which was made suitable for Markov Chains analysis. With the Markov Chains analysis, the statistical change rates table of the land classes for 2056 was created and the 2056 forecast map was produced by applying CA-Markov to the 2020 raster data with the help of the change rates table.

Eskisehir, which is experiencing a rapid urbanization process due to its developed urban dynamics, was chosen as the study area (Figure 1). In Eskişehir, where a metropolitan municipality was established in 1993 due to population growth and urban growth, the most prominent function has been industry (Şahbaz, 2016). After the industrial function that determined the urban identity, trade, agriculture and education functions gained importance. The increase in the urban population from 34,923 in 1980 to 783,611 in 2019 actually gives an idea about the extent of urban area growth. 


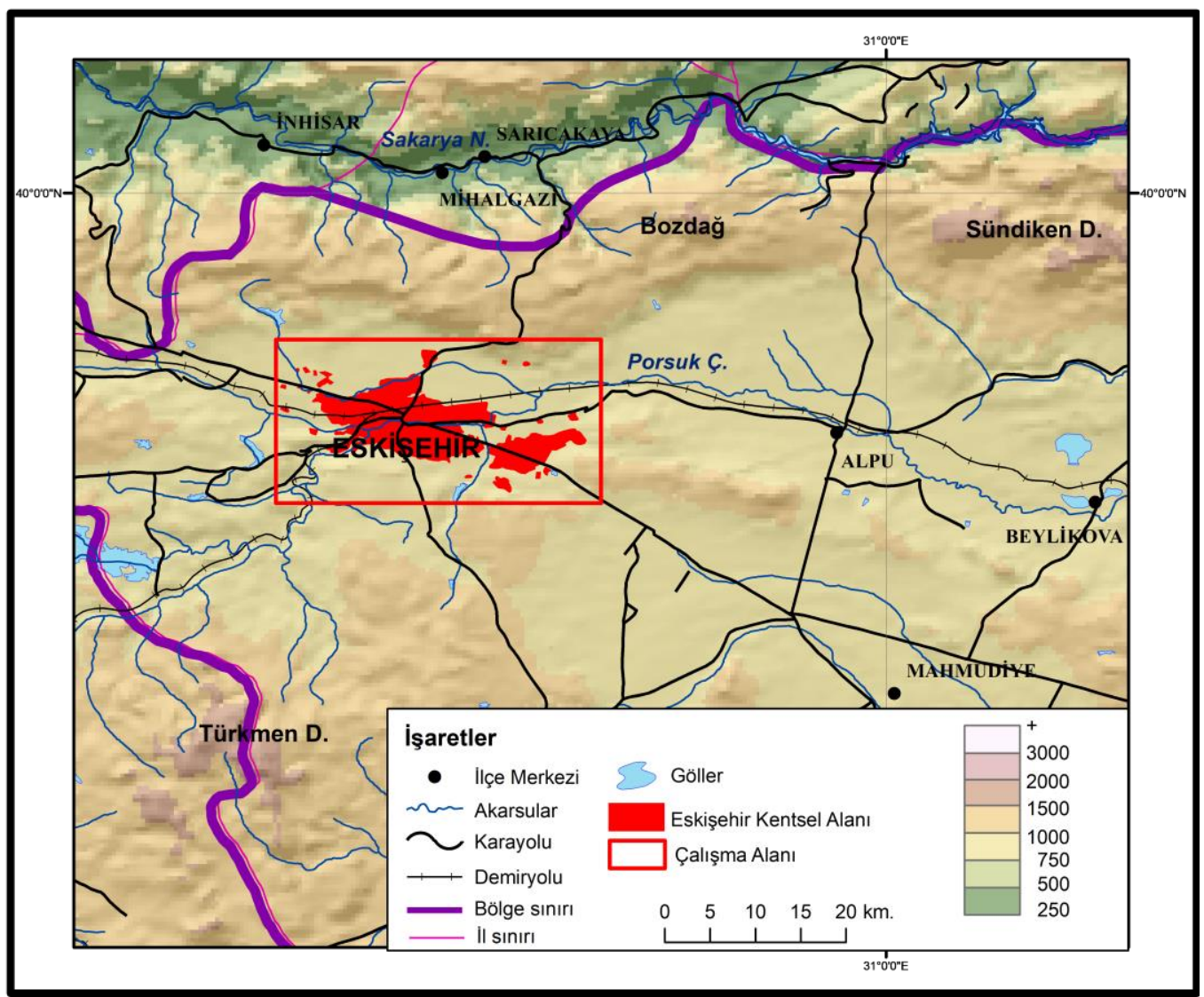

Figure 1. Study area

\section{Result}

In order to determine the change in the urban growth area of Eskişehir, the land cover classes produced from satellite images were analyzed separately for the years 1984, which was determined as the starting year, 2020, which shows the current situation, and 2056 as the projection forecast year.

According to the analysis made within the scope of the 5 land cover classes previously determined, in 1984, the urban area of Eskişehir was surrounded by agricultural areas. The spreading area of Eskişehir, which has a single centered feature, in this period has developed in the northwestsoutheast direction, depending on Ankara-Eskişehir, Eskişehir-Bursa highways and the industrial areas in its vicinity.

In 2020, Eskişehir urban area started to grow rapidly and started to develop in the north-south axis, and this spread was observed especially on the agricultural areas around the city. Urban growth has evolved from a unicentricity to a more centralized, and small urban spots separate from the city center speck have emerged. Shopping malls, which are the most important example of increasing consumption places in cities, have also increased in Eskişehir after the 2000s. Established in 2007, Kanatlı Shopping Center has also guided urban growth. The city continued to grow in parts with the transformation projects carried out in the shopping malls. Declaration of Eskişehir as the Turkish Cultural Capital in 2013 played a role in the evolution of urban growth. Odunpazarı, Kurtuluş Museum 
and Haller Youth Center, where historical buildings renovated for domestic tourism are located; spaces such as Kentpark, Sazova Science Art and Culture Park, Science Experiment Center and Underwater World, which are designed as built environment; The Porsuk and its surroundings, organized to increase the environmental quality, have directly contributed to the growth rate and direction of the city, which has witnessed significant developments in terms of quality and quantity in urban tourism resources.

Markov Chains were used for the land cover classes determined for the years 1984-2020 and the rate of change was calculated. Accordingly, in 1984, 24\% of the agricultural lands in the urban area; In 1984, it was observed that the other field class transformed into urban areas with $12 \%$ in 2020 . This situation has been an indication that Eskişehir city area is spreading over agriculture and other areas. The expansion of the urban area and the increase in the need for transportation will cause the roads to become the most areally increasing class.

\section{Discussion and Conclusions}

This study, which was made to predict how and in what direction Eskişehir urban growth area will develop using Cellular Automat and CA-Markov models, provides a framework for the future view of the city. In this context, firstly, the change between 1984-2020 was analyzed with CA-Markov and its outlook in 2056 was determined based on these findings. When the results of the study are evaluated, the importance of GIS and Remote Sensing methods for understanding urban growth processes is revealed.

Eskişehir grew approximately 2 times (2.3) in terms of area in the period from 1984 to 2020, which is considered the starting year. According to the estimation map obtained, Eskişehir's urban growth will slow down relatively in the next 36 years and multi-center foci will merge over time. As a matter of fact, it is predicted that the small spots around Eskişehir urban area will develop mostly in the northwest direction in 2056.

The growth that took place roughly in the east-west direction on the transportation axis between Istanbul-Ankara metropolises in 1984, accelerated in the north-south direction in 2020, depending on the growth of the organized industrial zone. In the 2056 projection, it is predicted that the growth will continue in line with the current situation and the urban spots growing apart from the city center will merge over time and form a whole.

An urban growth scenario for Eskişehir is expected to benefit all decision-makers, especially urban planners. The analysis and interpretation of the changes by evaluating the city separately in terms of agriculture, vegetation, road and most importantly urban area in different years made it possible to predict the future development of the city. In this context, it can be said that both local government policies and the free market are effective in the development of the city. According to the findings of this study, it is recommended to develop planned and effective urban strategies considering the future situation of the city.

\section{Referanslar/References}

Alan, İ., Demirörs, Z., Bayar, R., Karabacak, K. (2020). Markov Chains based land cover estimation model development: The case of Ankara Province. International Journal of Geography and Geography Education, (42) , 650-667. doi: 10.32003/igge.722038. 
Altundal Öncü, M. (2015). Bir Kentsel Kamusal Mekân Olarak Parkların Kapitalist Kentleşme Süreciyle Üretiminin Yorumlanması: Dikmen Vadisi Örneği. Ankara Üniversitesi Sosyal Bilimler Enstitüsü, Yayımlanmamış Yüksek Lisans Tezi, https://tez.yok.gov.tr/UlusalTezMerkezi/TezGoster?key=WY5CM7tPNE2z_YM6pBuOtwohn3kKLf6J784k3aV4HnXEC OpW5Bz3jBQC9A8tqrOw adresinden edinilmiştir.

Aydın, O. (2011). CBS temelli Hücresel Otomata yöntemiyle kentsel büyüme modeli: Ankara örneği, Coğrafi Bilimler Dergisi, 9 (2), 135-157, doi: 10.1501/Cogbil_0000000122.

Canpolat, F., Dağlı, D. (2020). Elazığ İli'nde arazi kullanımı değişimi (2006-2018) ve simülasyonu (2030) . International Journal of Geography and Geography Education, (42), 702-723. doi: 10.32003/igge.746668.

Cengiz, S., Yılmaz, B. (2016). Malatya'da arazi kullanımı/örtüsünün modellemesi, 2025-2045 arazi kullanımı/örtüsü simülasyonu. UZAL-CBS 2016 Sempozyumu Bildiriler Kitabı içinde (49-57). Adana.

Cohen, J. (1960). A Coefficient of agreement for nominal scales. Educational and Psychological Measurement, 20 (1), $37-46$. doi: $10.1177 / 001316446002000104$.

Çağlıyan, A., Dağlı, D. (2015). Arazi kullanımında simülasyon modelleri ve entegre kullanımları. TÜCAUM VIII. Coğrafya Sempozyumu Bildiriler Kitabı içinde (233-245), Ankara.

Behera, M. D., Borate, M., Panda, S. N., Behera, S. N., Roy, P.R. (2012). Modelling and analyzing the watershed dynamics using Cellular Automata (CA)-Markov Model-a geo-information based approach. Journal of Earth System Science, 121 (4), 1011-1024. doi: 10.1007/s12040-012-0207-5.

Dewan, A. M., Yamaguchi, Y. (2009). Land use and land cover change in greater dhaka, bangladesh: Using remote sensing to promote sustainable urbanization. Applied Geography, 29 (3), 390-401. doi: 10.1016/j.apgeog.2008.12.005.

Feng, Y., Lei, Z., Tong, X., Gao, C., Chen, S., Wang, J., Wang, S. (2020). Spatially-Explicit modeling and intensity analysis of China's land use change 2000-2050. Journal of Environmental Management, 263, 110407. doi:10.1016/j.jenvman.2020.110407.

Halmy, M. W. A., Gessler, P. E., Hicke, J. A., Salem, B. B. (2015). Land use/land cover change detection and prediction in the Northwestern Coastal Desert of Egypt using Markov-CA. Applied Geography, 63, 101-112. doi:10.1016/j.apgeog.2015.06.015

Halaç, O. (2001). Kantitatif Karar Verme Teknikleri (Yöneylem Araştırması) (5. Baskı). Bursa: Alfa Kitabevi.

Hamad, R., Balzter, H., Kolo, K. (2018). Predicting land use/land cover changes using a CA-Markov Model under two different scenarios. Sustainability, 2018, 10 (10), 3421. doi: 10.3390/su10103421.

Houet, T., Hubert-Moy, L. (2006). Modeling and projecting land-use and land-cover changes with Cellular Automaton in considering landscape trajectories. EARSeL eProceedings, European Association of Remote Sensing Laboratories, 5 (1), 63-76. https://halshs.archives-ouvertes.fr/halshs-00195847/document adresinden erişilmiştir.

Iacona, M., Geneldy, E. A. M., Rania, W. (2012). Markov Chain model of land use change in the Twin Cities. Journal of Land Use, Mobility and Environment, 8 (3), 1-24. doi: 10.6092/1970-9870/2985.

İlgar, E. (2008). Kent Kimliği ve Kentsel Değişimin Kent Kimliği Boyutu: Eskişehir Örneği, Anadolu Üniversitesi, Fen Bilimleri Enstitüsü, Yayımlanmamış Yüksek Lisans Tezi, Mimarlık Anabilim Dalı, https://tez.yok.gov.tr/UlusalTezMerkezi/TezGoster?key=UPP_Zu9isEmWGFXFCBYasSus7l8ViQua5SXc_Qz9XuMK 5_kt22XY2s8uqZdLJayn adresinden edinilmiştir.

Jackson, R. D., Huete, A. R. (1991). Interpreting vegetation indices, Preventive Veterinary Medicine, 11 (3-4), $185-203$. doi:10.1016/S0167-5877(05)80004-2.

Karip Bozkaya, A. G., Göksel, Ç. (2017). İğneada koruma alanının arazi örtüsü/arazi kullanımının zamana bağlı değişiminin Markov Zincirleri ile modellenmesi. Journal of Geomatics, 2 (2), 94-105. doi: 10.29128/geomatik.303890.

Keleş, R. (2010). Kentleşme Politikası. (11. Baskı). Ankara: İmge Kitabevi.

Kurtuluş, K. (1983). İşletmelerde Araştırma Yöntemleri (Araştırma Yöntemleri). İstanbul: İ.Ü.Yayın No:3128.

Liu L., Wang X., Eck J., Liang J. (2005). Simulating Crime Events and Crime Patterns. F. Wang (Ed.), Geographic Information Systems and Crime Analysis içinde (197-213).

Mammadov, R., Rasuly, A., Mobasher, H., Mohamadzadeh, K. (2019). Applying an object-based classification approach through a Cellular Automata-Markov method in landcover/landuse change detection procedure "Case of the Urmia Lake". Konya Mühendislik Bilimleri Dergisi, 7 (3), 536-550. doi: 10.36306/konjes.612489.

Mansour, S., Al-Belushi, M., Al-Awadhi, T. (2020). Monitoring land use and land cover changes in the mountainous cities of 
Oman using gis and CA-Markov modelling techniques. Land Use Policy, 91, 104414. doi:10.1016/j.landusepol.2019.104414.

Mas, J. F., Kolb, M., Paegelow, M., Olmedo, M. T. C., Houet, T. (2014). Inductive Pattern-Based Land Use/Cover Change Models: A Comparison af Four Software Packages. Environmental Modelling \& Software, 51, 94-111. doi:10.1016/j.envsoft.2013.09.010.

Mondal, M. S., Sharma, N., Kappas, M., Gargc, P.K. (2013). Modeling of spatio-temporal dynamics of land use and land cover in a part of Brahmaputra River Basin using geoinformatic techniques. Geocarto International, 28 (7), $632-656$. doi:10.1080/10106049.2013.776641.

Muller, M.R., Middleton, J. (1994). A Markov model of land-use change dynamics in the Niagara Region, Ontario, Canada. Landscape Ecology, 9 (2), 151-157. doi: 10.1007/BF00124382.

Munthali, M. G., Mustak, S., Adeola, A., Botai, J., Singh, S. K., Davis, N. (2020). Modelling land use and land cover dynamics of Dedza District of Malawi using Hybrid Cellular Automata and Markov model. Remote Sensing Applications: Society and Environment, 17, 100276. doi: 10.1016/j.rsase.2019.100276.

Olmedo, C., Mas, J. F. (2018). Markov Chain. M. Teresa, C. Olmedo, M. Paegelow, J.F. Mas, F. Escobar. (Ed.). Geomatic Approaches for Modeling Land Change Scenarios içinde (441-446). Switzerland: Springer International Publishing AG.

Sang, L., Zhang, C., Yang, J., Zhu, D., Yun, W. (2011). Simulation of land use spatial pattern of towns and villages based on CA-Markov model. Mathematical and Computer Modelling, 54, (3-4), 938-943. doi: 10.1016/j.mcm.2010.11.019.

Şahbaz, H. (2016). Odunpazarı ve Tepebaşı İlçelerinin (Eskişehir) Beşeri ve Ekonomik Coğrafyası. Uşak Üniversitesi Sosyal Bilimler Enstitüsü. Yayımlanmamış Doktora Tezi, https://tez.yok.gov.tr/UlusalTezMerkezi/TezGoster?key=Br_XTptK8CZ70fOJGX9xEvTGZBfoQcMgangROif1sgm3AB $x C d r b D p y T Y C h \_d Q V a L$ adresinden edinilmiştir.

Soykan,Y. (2010). Markov zincirleri ile pazar payı araştırma modeli ve otomobil lastiği pazarında bir uygulama. Dumlupınar Üniversitesi Sosyal Bilimler Dergisi, (27), https://dergipark.org.tr/tr/pub/dpusbe/issue/4769/65601 adresinden edinilmiştir.

Timor, M. (2001). Yöneylem Araştırması ve İşletmecilik Uygulamaları. İstanbul: İstanbul Üniversitesi Basımevi Müdürlüğü, İşletme Fakültesi Yayın No:280.

Yazıc1, A., Öztürk, D., Ayazlı, İ. (2019). Kentsel büyümenin modellenmesi ve simülasyon modelleri, International Journal of Multidisciplinary Studies and Innovative Technologies. 3 (1), 44-47. https://dergipark.org.tr/tr/pub/ijmsit/issue/43647/518641 adresinden edinilmiştir.

Yüzer M. A., Yüzer, Ş. (2006). Cellular Automata tabanlı LUCAM modeli ile İstanbul'un gelişim ve dönüşümüne ilişkin makro form simülasyonları, Journal of İstanbul Kültür University, 4, 231-244. https://acikerisim.iku.edu.tr/bitstream/handle/11413/429/IKUGuncesiFenveMuh.Bilm.Cilt4Sayi4Aralik2006MehmetA liyuzer.pdf? sequence $=1$ \&isAllowed $=y$ adresinden erişilmiştir. 